\title{
Binary Oppositions and Defiance to Phallogocentrism in Caryl Churchill's Owners
}

\author{
Pareia Bakhshi \\ Department of English Language and Literature, Lorestan University, Khorramabad, Iran \\ E-mail: pareiabakhshi@yahoo.com
}

Received: 15-01-2013

Accepted: $15-02-2014$

Published: 01-05-2014

doi:10.7575/aiac.ijalel.v.3n.3p.232

URL: http://dx.doi.org/10.7575/aiac.ijalel.v.3n.3p.232

\begin{abstract}
Throughout Western history, the phallogocentric orientation of Western society and culture has perpetually and painstakingly striven to create the illusion of the priority and superiority of masculinity over femininity in order to reach its ultimate goal of ever-lasting dominance. Women's oppression and subordination by the hegemonic masculinist culture has been resultant of the creation, perpetuation and deification of the binaristic frame of thinking that is considered to be at the heart of Western thought and philosophy. In the present study, the absurdity and hollowness of phallocentric gender binarism in Caryl Churchil's Owners is explored and dismantled via the depiction of those characters in Caryl Churchill's selected play which deviate from the long-held gender-specific codes of behavior. And this is implemented with an eye to Butler's theorizations on "gender performativity".
\end{abstract}

Keywords: Caryl Churchill, Judith Butler, binaristic frame of thinking, gender binarism

\section{Introduction}

Throughout Western history, the phallogocentrism-oriented Western culture has always struggled hard to inculcate the inferiority of women and the superiority of men with the help of all the available discourses it had under its sway like science and religion. Therefore, throughout the Western history and due to the fulsome inculcations of the phallogocentric system of thought, men have always been biasedly assigned such positive attributes as rationality, strength, loyalty, honesty, firmness and so on, while women have historically been associated with negativity, frailty, wickedness, weakness, tenderness, irrationality, and sentimentality. As Sarah Gamble (2002) states:

Women are treated inequitably within a society which is organized to prioritize male viewpoints and concerns. Within this patriarchal paradigm, women become everything men are not (or do not want to be seen to be): where men are regarded as strong, women are weak; where men are rational, they are emotional; where men are active, they are passive; and so on. Under this rationale, which aligns them everywhere with negativity, women are denied equal access to the world of public concerns as well as of cultural representation (p.vii).

Thanks to all those efforts and struggles on the part of patriarchy and phallogocentric hegemony, the Western thought and culture became successful to eternally associate femininity with negativity and masculinity with positivity and to establish these attributes as natural and inherent; and by doing so, it was able to continue its sovereignty for centuries. And since women had become equivalent to negativity (emotionality, irrationality, infidelity, weakness, etc.) in the Occident, they were driven out of the public sphere into household domain.

In his Education of a Christian Woman, the humanist Juan Luis Vives provides us with a brief sketch of the prejudices and oppressions under which women have been living throughout Western history:

[I]t neither becometh a woman to rule a school, nor to live among men, or speak abroad, and shake off her demureness and honesty, either altogether or else a great part: which if she be good, it were better to be at home within and unknown to other folks. And in company to hold her tongue demurely. And let few see her, and none at all hear her.... For Adam was the first made, and after Eve, and Adam was not betrayed, the woman was betrayed into the breach of the commandment. Therefore because a woman is a frail thing, and of weak discretion, and that may lightly be deceived: which thing our first mother Eve sheweth, whom the devil caught with a light argument. Therefore a woman should not teach, lest when she hath taken a false opinion and believe of anything, she spread it into the hearers (qtd. in Loughlin et al., 2010, p.106).

The writings of St. Paul in the New Testament in which the appropriate wifely behavior and the complete subjection of women is declared were also a source of inspiration for male-tyranny to subjugate women further:

Wives, submit yourselves unto your own husbands, as unto the Lord. For the husband is the head of the wife, even as Christ is the head of the church: and he is the saviour of the body. 
Therefore as the church is subject unto Christ, so let the wives be to their own husbands in everything. [Ephesians 5:22 King James Bible]

But what constitutes the basis of the present study is to delineate the falsity of all those ideas through the utilization of the Butlerian key concept of gender performativity in the analysis of Churchill's selected play Owners. In other words, what we have undertaken in the present article is to designate how Caryl Churchill as an internationally distinguished playwright proclaims her own defiance to these century-old inculcations and binaristic frame of thinking.

\section{Discussion}

As Butler (1990) articulates, gender is not an inherent property of the subject; it is culturally constituted and gains its naturality through the "stylized repetition of acts" (p. 3) "within a highly regulatory frame". In fact, these "acts and gestures, articulated and enacted desires create the illusion of an interior and organizing gender core, an illusion discursively maintained for the purposes of the regulation of sexuality within the obligatory frame of reproductive heterosexuality" (Butler, 139).

In the Owners (1972) Churchill weaves together her anti-capitalistic and anti-authoritarian views with her critique of the artificiality of the assigned gender roles under the reign of the heterosexual hegemony. She wrote the play in 1972 when the Tory leader Edward Heath was in power. As Jane E. Howard believes, the Owners is Churchill's response to "the urgent social issues of the day", so it is "refuelled by the urgent sense that a lot is at stake in the then ongoing struggle over whether and how the beast of capitalism would be contained and its violence blunted by regulation"(Aston and Diamond, 2009, p.37). On the other hand, since Churchill has a strong commitment to both socialism and feminism, she coalesces both in the Owners, his first professionally produced play, which is composed of two acts. In this drama Churchill tries to warn us against the devastating effects of not only capitalism but also any hegemonic systems which lead to the hierarchization of the society based on class, gender, race and so on. Through envisaging a dystopia in the Owners resulted from turning a blind eye to this fundamental principle, Churchill repeats Butler's remarks that even "feminism ought to be careful not to idealize certain expressions of gender that, in turn, produce new forms of hierarchy and exclusion" (Butler, 1990, viii). But what is going to be concentrated on in this study is to look at the play through a Butlerian lens. Therefore, the key Butlerian idea of performativity will be taken into consideration in the analysis of the play and its characters in order to display that the most agreed-upon and the most highly-inculcated concepts of femininity and masculinity are not as inherent and as natural as perceived.

Churchill's strategy to call into question the gender identities enshrined in the dominant discourse of heterosexuality is to reverse the gender roles and attributes traditionally and historically assigned to both males and females. In the Owners, the female characters illustrate male attributes, while the male characters display feminine traits. By doing so and reversing the gender roles and attributes, Churchill suggests Butler's conviction that gender is not an "interior essence", but it is "manufactured through a sustained set of acts", thus it is performative (Butler, 1990, p. xv). In fact, what we consider to be "an internal feature of ourselves" is what we "produce through certain bodily acts", therefore gender is a "hallucinatory effect of naturalized gestures" (Butler, p.xv). In the other words, she believes that "Gender is a kind of enforced cultural performance" (Jagger, 2008, p. 20).To get a better grasp of Churchill's strategy in the Owners, it becomes necessary for us to investigate the Churchill's characterization of the main characters because the main characters here demonstrate characteristics conventionally regarded to be improper to their sex and proper to their opposite sex. For instance, we have Marion who is "the powerful rich property developer" who appears to be bereft of any feminine traits versus Alec whose inordinate inaction and passivity is exemplary. Or we have Worsely whose squeamishness and tenderness and his proclivity to commit frequent suicides due to his inability to tolerate reminds us of traditional assumptions of femininity. Or even Clegg whose masculinity is just verbalized but not actualized.

The main female character in the drama is Marion, Clegg's wife and Alec's lover, who is devoid of any feminine traits. In spite of her husband's reluctance and despite his declarations that women should busy themselves with creative and artistic things such as painting, Marion owns a real estate agency and is all the time indulged in such masculine tasks and traits as buying and selling houses, eating voraciously, hardness, lack of subservience, lack of sentimentality, and ruthlessness. She works very hard; she is physically strong; she goes to karate classes; she "eats in bed and sleeps at her desk" (Churchill, 1996, p. 27); "she works like a dog" and announces that "Most women are fleas, but I am the dog"(Churchill, p.30). Her determination is so exemplary that she becomes the embodiment of determination in the Owners: "We men of destiny get what we are after even if we are destroyed by it"(31). Her abundant determination becomes manifest in the words she utters about her aims and doctrine:

... I want to hold on. Everything I was taught- be clean, be quick, be top, be best, you may not succeed, Marion, but what matters is to try your hardest. To push on. Onward Christian soldiers, marching as to war. That was my favorite song when I was seven. Fight, the good fight (Churchill, p.30).

Marion's excessive possessiveness is another characteristic that unveils her defiance to the traditionally assigned roles imposed on subjects under the patriarchal hegemony. She is pathologically disposed to possess and own not only the houses and apartments as a real estate developer but also humans. Her thirst to possess is insatiable. Although she is a very prosperous developer, she doesn't feel any sympathy for anybody even for her former lover Alec and his family. In a conversation with Alec, she lectures on her philosophy and articulate cruelty and heartlessness and guilt as the essential factors to her success: 
Doesn't evolution say the same? Keep on, get better, be best. Onward. Fight. How did man get to the moon? Not by sitting staring at an orange. [...] You would be content on a flat earth. But the animals are ours. The vegetables and minerals. For us to consume. We don't shrink from blood. Or guilt. Guilt is essential to progress. You'll tell me next you don't feel guilt. [...] I see children with no shoes and socks in the houses I buy. Should I buy them socks? It would be ridiculous (Churchill, 1996, p. 30).

As witnessed, Marion's character is in complete contrast with the traditional assumptions about womanhood and femininity. She does whatever she can to dislodge them and to acquire her lost love. She deprives Alec and his wife of their own right as father and mother and tries maliciously to get legal possession of their baby in order to make Alec succumb to her love. Her endeavors to possess Alec do not stop, even if his efforts lead to Alec's destruction and death as it does. In Marion's eye, everything can be purchased and possessed. When she is supplicated by everybody to return Alec and Lisa's baby, she makes an analogy between herself and the Genghis Khan and verbalizes her ruthlessness:

Every one of you thinks I will give in. Because I'm a woman, is it? I'm meant to be kind. I'm meant to understand a woman's feelings wanting her baby back. I don't. I won't. I can be as terrible as any one. Soldiers have stuck swords through innocents. I can massacre too. Into the furnace. Why shouldn't I be Genghis Khan? Empires only come by killing. I won't shrink. Not one of loves me.But he shall grow up to say he does (Churchill, 1996, p.63).

Her ruthlessness reaches an acme and manifests itself more at the end of the play. When she, who has ordered Worsely to set Alec's house ablaze, discovers that Alec along with their neighbor's baby has gotten stuck in fire, indifferently states, "I'm not sorry at all about Alec. Or about that other baby. Not at all. I never knew I could do a thing like that. I might be capable of anything. I'm just beggining to find out what's possible" (Churchill, 1996, p.67).

The combination of all these characteristics is what makes Marion appear to be opposing the conventionally ingrained ideas about femininity and feminine roles. By creating such a female character, who has appropriated masculine roles and traits, Churchill has been able to achieve her goal of challenging not only the heterosexual discourse but also the false assumption of confirming the fixity of gender roles and gender attributes. As a result, what is proven is what Butler has cited and that is the constructedness and performativity of gender roles. It is demonstrated that it is possible for the subject to enact and show the attributes that do not conform to its biological sex and the established norms considered to be appropriate in the heterosexist society.

Alec, Marion's antithesis, represents a man who disturbs and unsettles all the definitions about manhood presented and perpetuated in the heterosexual culture. He is completely passive and devoid of any sense of possessiveness. Although he was a professional glazier, he has not been at work for six months and he is always "sitting here quietly. Doing nothing"(Churchill, 1996, p.14); "He doesn't remember to eat" if Lisa doesn't remind and make him (Churchill, p.24); and as Lisa frequently states, "he just wants nothing"(Churchill, p.25). His inordinate passivity and lack of possessiveness is quite manifest in several parts of the play; for instance, when they return home and see their house burglarized, his reaction contradicts what we expect from a man brought up in a patriarchal society like ours:

Lisa: If we're very quick, they might just catch them.

Alec: I wouldn't mind them caught.

Lisa: What is it now?

Alec: If he wants the things that much, perhaps let him have them.

$[\ldots]$

Lisa: If we'd come in when he was still here, you wouldn't have grabbed him.

Alec: No (Churchill, 1996, p.13).

Even when Lisa states that "If we'd found him murdering the boys you'd have stood there"(Churchill, 1996, p.13), no response is heard from Alec, a fact which confirms his bizarre indifference and passivity. Indeed, nothing can make him move and nothing can stimulate him into action because he believes that "without that clock ticking. Nothing is moving at all"(Churchill, p.14). His excessive neutrality is again witnessed when Marion is trying to convince him to leave Lisa:

Alec: I don't think I could say I loved anyone more than anyone else.

Marion: You love me more than a complete stranger.

Alec: I couldn't say for certain. I can say I love you and Lisa. But it wouldn't matter if I never see you again.

Marion: You love your children more than someone else's.

Alec: Not necessarily. You see (Churchill, p.47).

When Worsely, Marion's agent, comes to talk them into leaving their apartment during a five-page conversation, Alec stays silent and does not interfere even when he is looked at by both Lisa and Worsely to participate in the conversation. By portraying such a character as Alec, who is in complete contrast to the expected-as-normal definitions of manhood in the heterosexual regimes, Churchill emphasizes Butler's ideas about the constructedness of such terms as femininity and masculinity and considers the possibility of the emergence and existence of other forms of gender identity which do not match the conventional criteria regarding such terms. 
Clegg is another male character in the play who can also be helpful in verifying the reversibility and thus performativity of gender identities for he invalidates the traditionally and historically ingrained norms considered as masculine through his behavior. He is a character through which we can see the collapse and subversion of male tyranny. He demonstrates that male chauvinism has plunged into a dip in the new system of thought and discourse. Clegg, an unsuccessful butcher who has to leave his business because he lacks the capability to compete with the newly-opened chain store in the neighborhood, is utterly dissatisfied with his present situation as Marion's so-called husband, and is frequently seen conversing with Worsely about how to kill and get rid of her because he thinks that his masculinity has been undermined and underrated by Marion. He feels a vacuum inside and broods over his lost dignity by comparing his situation with his father's:

We were taught to look up to my father. My mother literally worshipped him. I've seen her on her knees. And he would raise her up, very gracious. She knew how to give a man the right support. He had his chair. The tea was hot on the table when he came in. We never made a sound (Churchill, 1996, p.9).

His lost dignity as a man, who considers himself as the watchdog of the traditional perceptions about manhood and womanhood, becomes more evident when we see him financially dependent on Marion and involved in domestic affairs such as taking care of the baby for whom Marion has bought, carrying the baby in a carrycot, heating the baby's bottle and so on.

Although Clegg is biologically masculine and claims to be a male chauvinist, his involvement in tasks conventionally considered to be feminine, his subservience to Marion, his financial dependence on her, his cowardice in front of her all illustrate that although he is biologically masculine and claims to be a male chauvinist, he lacks the attributes traditionally regarded to be necessary in men in order to maintain manhood. In Clegg's opinion, women, babies and cowards are equivalent. But When Lisa tries to persuade Clegg to return her the baby, Clegg refuses and his only reason, as stated by him himself, is being afraid of Marion:

If I was to give you the baby I wouldn't dare see her again. I don't care how angry you are, it's nothing like. With Marion it's like a mad person, you don't want to be in the same room, you don't want their attention to fall on you. It's not something I'd expose myself to. [...] She might commit a crime (Churchill, 1996, p.54).

In different parts of the drama, Clegg also attribute terms as squeamishness, physical weakness and incompetence to women; he also calls women the "fair sex" and cowards; and he abhors women standing on their own feet; but throughout the play, it is the women like Marion and Lisa on whom men rely for every kind of support; and it is the men who show inordinate passivity, squeamishness and sentimentality, hesitation and passivity; and it is they(male characters) who can be called "the fair sex".

In the Owners, as we observe, Clegg is leading life in a world in which everything has been turned upside down; his assumptions that represent the traditional perceptions about not only manhood and womanhood but also the propriety of gender roles have been subverted and turned upside down. In fact, what has paralyzed the male characters in the play and has driven them out of their solace of manhood into displaying feminine traits is their dethronement from their century-old power and the enthronement of their opposite sex. In this new system of thought and power, we can see not only the emergence of new identities but also fluctuations and frequent deviations from the long-established traits. The existence and emergence of such deviations from the historically and traditionally settled norms, deemed to be appropriate for gender identities, all imply the inherent instability of gender identities and roles which underlies Butler's contention regarding the "performativity" of gender identities.

\section{Conclusion}

The reversibility of gender roles in the Owners illustrates that gender identity, which has historically been regarded to be stable and unwavering, is not something fixed and unalterable, but it is an entity at the mercy of diverse sociocultural factors. In the newly-emerged and congenial atmosphere, in which women can gain access to the previously exclusiveto-men domains, we see the appearance of a woman who transgresses the traditionally imposed roles and attributes. This transgressive woman, who defies what has historically been imposed on women as natural and inherent, demonstrates the possibility of going against the long-rooted norms prescribed by the age-old patriarchy and consequently implies the artificiality of all the norms and roles prescribed and impelled by the dominant discourse of patriarchy. In the Owners, although Caryl Churchill as a feminist portrays a kind of society in which we encounter the reversal of gender roles and identities and even gender hierarchies, she does not idealize such a female-dominated society. In fact, she creates a dystopia in which Marion the female "Genghis Khan" of the play proceeds and ruthlessly ruins whatever stands on the way of her success and accomplishments. Churchill's abstaining from the idealized portrayal of such a female-dominated society unveils her fear of the establishment of a new hegemony and hierarchy. The principle Churchill pursues in the Owners by portraying such a dystopia and urging the audience to take heed is what Butler seeks and expresses in her Gender Trouble, "feminism ought to be careful not to idealize certain expressions of gender that, in turn, produce new forms of hierarchy and exclusion"(Butler, 1990, p.viii). 


\section{Reference}

Aston, E. \& Reinelt, J. (eds). (2000). The Cambridge Companion to Modern British Women Playwrights. Cambridge: Cambridge University.

Butler, J. (1990). Gender Trouble: Feminism and the Subversion of Identity. NewYork: Routledge.

Churchill, C. (1996). Plays:One. London: Methuen.

Gamble, S. (2002). "Gender and Transgender Criticism". Introduction to Criticism at the 21st Century. Ed. Julian Wolfreys. Edinburgh: Edinburgh U P.

Jagger, G. (2008). Judith Butler: Sexual politics, Social Change and the Power of the Performative.London and New York: Routledge.

Loughlin, M., Bell, S. J., \& Brace, P. (2012). (eds). The Broadview Anthology of Sixteenth-Century Poetry and Prose. Canada: Broadview Press. 